\title{
Between Body and Spirit: The Liminality of Pedagogical Relationships
}

\section{SHARON TODD}

\begin{abstract}
This article explores the pedagogical, transformative aspects of education as a relation, viewing such transformation as occurring in the liminal space between body and spirit. In order to explore this liminal space more thoroughly, the article first outlines a case for why liminality is of educational and not only of pedagogical concern, building on James Conroy's notion of the liminal imagination and his emphasis on the importance of metaphor for calling our attention to the ontological spaces that make up educational practice. I then use this metaphor both substantively and methodologically, offering a reading of Clarice Lispector's novel The Stream of Life as a performance of the liminal imagination in its attempt to put into focus the embodied and transcendent aspects of becoming, both of which I see as central to defining what is pedagogical about human existence. The article then turns to developing how different metaphors may be mobilised to signify the particularly relational quality of becoming, drawing on Luce Irigaray's work to explore more closely the corporeal and spiritual aspects of becoming in relation. I then turn my attention to a more fulsome discussion of the significance of approaching pedagogical relationships in education in this way and what this signifies for the teacher-student encounter in particular.
\end{abstract}

... I hardly exist and if I do exist it's with a delicate care. Surrounding the shade is a teeming, sweaty heat. I'm alive. But I feel I've not yet reached my limits, bordering on what? Without limits, the adventure of a dangerous freedom. But I take the risk, I live taking it (Clarice Lispector, The Stream of Life).

After our parents and caregivers, the most common relationship that many of us experience is the one with our teachers. From an early age we come into encounters, more or less warm and inviting, severe and distant, with teachers from whom, if we are lucky, we learn not just about what we are, 
but who we are. Such learning, in my view, occurs not simply through the curriculum, but through moments that punctuate the apparent continuity of classroom routine-small, transformative moments, to use Lispector's words, of 'delicate care' that disrupt the commonplace. It is nothing overt or explicit, nothing that can be articulated fully through words, but a subtlety of presence that allows a bit of life in all its messiness to enter:

A teacher standing near, the feeling of goosebumps, a warmness creeping from the centre of my body radiating out to my limbs. I am seven years old and sense, without having to see, my teacher hovering over my shoulder. Wanting to smell her scent, to feel her breath against my cheek and to glimpse the baby-fine hairs on her own, to touch her skin, knowing it would be warm. The nearness of it all-her presence, my awareness-almost painful, yet full of pleasure. It is sudden and I'm a bit frightened of what's happening. No contact, no touching, yet something palpable and close. I do not understand this, I sense it, and I am different.

I have often thought about this moment_and similar ones-over the course of a lifetime in classrooms as both teacher and student. I recollect this here in the context of this special issue on relationships, for I think there is something profoundly pedagogical in moments such as these. Such moments are pedagogical not because they occur in educational contextswhich they can and do-but these moments also constitute what is 'educational' about life: that through our encounters with others (human and non-human alike) we shift the borders of our self understanding. That we alter and transform in this way is not merely the hope of education, but is the pedagogical act of living par excellence.

From the earliest conceptions of education, the transformation of the self was recognised as belonging to an encounter with a teacher (witness the Socratic questioner; the Voltairean gardener; the Deweyan guide. Although much educational philosophy has grappled with the proper image of the teacher in order to bring forth the desired changes in students, I want to shift the focus here in order to highlight the relationship between teacher and student itself as a specifically pedagogical onepedagogical because the relationship occasions transformation and becoming (Castoriadis, 1997). ${ }^{1}$ This means that all kinds of relationships are pedagogical - one can speak of the pedagogy of a film or text (Lusted, 1986), just as one might speak of what one becomes in relation to a colleague, pet or friend. However, unlike the pedagogical aspects of a relationship, say, between siblings, friends, colleagues or lovers, the relationship between teacher and student is doubly so, since it rests upon an educational intentionality, or 'demand' for change (Todd, 2003), that these other relationships do not.

In this sense, reimagining educational relationships as specifically pedagogical ones requires moving beyond our intentionality (or at least bracketing it off momentarily), in order to uncover the aspects of relationality that occasion one's becoming. That is, that people change and become is 
not always dependent upon the intentionality behind the circumstances. Teachers can desire certain changes in their students, but students' lives change in unpredictable ways, outside of these desires. As the recollection above indicates, change can occur in a mixture of disturbance and delight: it disturbs in terms of the unknowingness it opens up, generating feelings of being overwhelmed, and it carries with it an intensity of physical sensation that itself can be unsettling as well as deeply pleasurable and erotic. In this sense, the transformation involved in one's becoming is rarely easy. The quote from Clarice Lispector intimates that living life is about exceeding limits, about living it as a risk. Life resides in mystery and excess: we do not know what awaits. And life is also not what we live in containment, cut off from the senses, but about being exposed to the 'teeming, sweaty heat' by which we know we are alive. In this sense it is bodily and beyond the body simultaneously: it is a sensibility that also gestures toward an unnameable openness beyond our limits. Existence, on this meaning, lies between the corporeal and a sense of limitlessness, or what I here refer to as spirit. $^{2}$

In order to explore this liminal space in between body and spirit, the article first outlines a case for why liminality is of educational and not only of pedagogical concern, building on James Conroy's notion of the liminal imagination and his emphasis on the importance of metaphor for calling our attention to the ontological spaces that make up educational practice. I then use this metaphor both substantively and methodologically, offering a reading of Clarice Lispector's novel The Stream of Life as a performance of the liminal imagination in its attempt to put into focus the embodied and transcendent aspects of becoming, both of which I see are central to defining what is pedagogical about human existence. It is here through her literary language that we can begin to approach the subtle, aesthetic quality of one's experiences of becoming. The article then turns to developing how different metaphors may be mobilised to signify the particularly relational quality of becoming, drawing on Luce Irigaray's work to explore more closely the corporeal and spiritual aspects of becoming in relation. I then turn my attention to a more fulsome discussion of the significance of approaching pedagogical relationships in education in this way and what this signifies for the teacher-student encounter in particular.

\section{THE LIMINAL IMAGINATION, METAPHOR AND EDUCATION}

There have been many ways of capturing the transformation of the self, and it is no secret that modern education has been built upon the idea that students not only can but ought to change, develop, and progress. Indeed, in a very obvious sense, educational discourses of all philosophical persuasions have used metaphorical language to 'capture' this change in learning. For instance, John Dewey speaks of growth, Jean Piaget and Lawrence Kohlberg of stages, Nel Noddings of flourishing, and Martha Nussbaum of cultivation. Within the current climate of economic efficiency, students' capacities for change are spoken of in terms of outcomes, productivity, and 
standardisation. Metaphors are akin in this regard to what Deleuze and Guattari (1994) say of a concept: ${ }^{3}$ 'it posits itself and its object at the same time as it is created' (p. 22). A concept, on their view, generates a certain landscape of 'reality' in creating new objects of thought. Metaphors, like concepts in this sense, approximate and focus our attention on certain 'things' rather than others, and in fact bring into being certain relationships that would not have been possible before. For example, Dewey's (1969/1938) metaphor of growth calls forth a relation whereby the teacher acts as someone who tends to and guides the student along her path of educative experience; Morwenna Griffiths (in this issue) shows how the language of the natural in Rousseau signals a particularly gendered set of relationships; and the economic metaphor of outcomes sets up a quality of relationality whereby the teacher is to focus primarily on the results or products of 'learning' instead of on its processes or its connections to the student herself. In order, then, to bring something into our field of awareness a shift in our metaphorical language is required to initiate new ways of thinking and practicing education. I argue here that exploring the existential dimensions of pedagogical relationships between body and spirit similarly requires a language of in-betweenness, or liminality, that gives full weight to the complex processes of human becoming.

James Conroy (2004) in Betwixt and Between: The Liminal Imagination, Education and Democracy makes a case for the importance of liminality for education, and outlines its reliance on metaphor. Writing against the backdrop of what he sees as an impoverishment of educational discourse around actual classroom practice, Conroy seeks to open up classroom space by developing the metaphor of the threshold, or liminality, as a way of discussing the human, existential quality of educational settings. For Conroy, liminality serves to act as a 'heuristic metaphor' 'to delineate particular kinds of ontological spaces in and around the school' (p. 57). As such, the liminal 'operates' in-between categories and spaces that sit 'at the threshold of experience' (pp. 7-8). Although his work is concerned with how these spaces exist on the threshold of social, political, cultural and religious intelligibilities, in pointing to the specifically ontological possibilities that such spaces offer Conroy nonetheless opens up the practice of education to its own role in human becoming. He suggests that with respect to education, the notion of liminality can be deployed in three ways: a liminal education, a liminal disposition, and liminal communities. It is the first two of these that holds particular relevance for the pedagogical relationship between teacher and student and thus I confine my discussion to these.

Conroy argues that a liminal education needs to acknowledge the ways in which ontological possibilities are created outside the structuring intentionalities of teaching: '. . . much of human thought, reflection and engagement with the world emerges out of the cracks and fissures of our personal and social relations and not in the wide-open structured spaces' ( $p$. 62). This means that the asymmetrical power dynamics which structure teacher-student relations are sometimes disrupted by such liminal spaces. 'In the liminal moment both are equal in the face of this or that encounter 
with an idea, a creation, comprehension or insight. No longer is there a separation between teacher and student-each learns, each encounters' ( $p$. 62). In what he refers to as his second deployment of the metaphor, he writes of developing a liminal disposition of the teacher that can aid in preparing and fashioning possibilities for these moments to happen. 'Practically, this entails the willingness to take chances, the capacity to let things take their own course, the patience to hang back' (p. 65). Conroy suggests that what is required on the part of teachers is a vision for cultivating their own and others' imagination. This is not a call for teachers to live 'in a world of as if' - as if their work were not deeply shaped by social, economic and cultural pressures and only needs to embrace an 'ideal' of liminality in order to dispense with them. Eschewing this kind of illusory practice, Conroy instead suggests that 'such a vision entails the recognition that the liminal is not, by definition, the main fare of the day, rather that the day is configured in the light of it' (pp. 65-66). The liminal, therefore, acts as a horizon of possibility that guides teachers' educational work.

There are two things particularly worthy of note in this depiction of a liminal education and liminal disposition. First is that Conroy implicitly gestures to the 'momentary' nature of liminal encounters; that is, while they can be enhanced by a certain 'disposition' on the part of the teacher, they rise up of their own accord, in an engagement with texts, ideas, and others in the present. Thus, immanent to the quality of liminality is an understanding of the importance of the here and now for initiating human becoming. ${ }^{4}$ Secondly, the separation of teacher and student perhaps does not so much disappear, as Conroy seems to suggest, but is rather, in my view, recast in a new register where the categories of teacher and student are suspended; it is more that the opportunities for becoming - and not the roles as suchbecome more equal in liminal encounters. Thus, the metaphor of liminality seeks to bring into our field of awareness the deeply personal aspects of becoming which are always connected to our living in the present moment, beyond-or perhaps in spite of-the regulatory roles we occupy in classrooms.

Conroy also avails himself of metaphor in another sense in introducing the liminal imagination. This is not only a metaphor that stands for the whole of his liminal project, it also signals the specifically literary, artistic, and poetical dimensions of human existence. There is a sense here that the way to create better conditions for liminal spaces to emerge in education is for teachers to turn to the qualities of relationality opened up by the arts. ${ }^{5}$ Conroy signals out the especial place poetry can occupy in this project: '. . . poetry which draws on its linguistic heartland-metaphor, aphorism, banal and sublime descriptions of the everyday-is never contained by, or reduced to, that heartland since it twists and stretches those very ordinary words so that it persistently pushes at the very edges of communicative possibility' (p. 12). Poetry, on Conroy's meaning, is itself a liminal form of expression whose purpose is not to 'name' but to suggest, intimate, and approach. Metaphor is not confined to syntactical substitution of one word for another, but it 'also plays a semantic role in that it offers us a new way of relating to its object; it enables us to generate new images, new 
sensations and changes in emotional states' (p. 150). Poetical expression thereby performs the very conditions of meaning that Conroy is seeking to employ in classroom spaces.

With this, the liminal imagination becomes, in my view, both an orientation to teaching and education at the same time as it calls forth an alternative mode of theorising education. As for the former, liminality reframes our attention to the ontological aspects of education that are bound to our everyday, lived experiences in classrooms. As for the latter, the liminal imagination functions methodologically to delineate an approach that uses literature, poetry and the arts in order to explore the liminal spaces of existence as central to educational thought. It is in the spirit of this methodological sense of the liminal imagination that I turn now to explore Clarice Lispector's The Stream of Life in order to explore the experience of existing in its everydayness.

\section{THE PEDAGOGICAL AS AN EVERYDAY EXISTENTIAL EXPERIENCE}

Clarice Lispector's (1989/1974) experimental novel, The Stream of Life, ${ }^{6}$ unfolds in present time; the nameless main character is a disillusioned painter who has recently turned to writing to try to express her 'existence' as it gets created, or creates itself, moment by moment, instant to instant. It is a lyrical, impressionistic work, with no real plot or narrative, and the language is far more poetic in its aim and structure than what is usually associated with the novel form. The narrator (if we may be permitted to call her that) writes the text as a letter of sorts to a past lover, persistently addressing herself to the question of who she is 'in this instant'. What she continually returns to is the ineffable quality of existence and its rootedness in liminal spaces that resist codification. Echoing Conroy's remarks above in relation to poetry, Lispector reveals not simply the limits of language, but the ways in which language pushes us to a point beyond our communicative possibilities.

Lispector uses language as a means for performing existence as a 'coming-into-being' (p. 51) located between the body and what lies beyond it: 'it is subtle, like the most intangible reality' (p. 15) yet it has, as we will see, a tangible, corporeal quality along with its 'spiritual' dimension. This coming-into-being entails 'a full stretching to the point where the person can stretch no more' (p. 51). Here, the narrator marks one's becoming as a process of alteration that is built on a certain plasticity of experience. It is a stretching out beyond our limits, both figuratively and literally, occasioning a different form of being. Hers is a unique bodily existence where the 'blood is thankful' and where 'pain is exacerbated life' (p. 51), and yet this existence pushes into unknowable spaces and becomes 'something more magical and more graceful' (p. 56) than what we can even contemplate or physically inhabit.

Lispector attends keenly to what it is we can neither articulate through words nor capture through understanding. In the novel, existing, living and becoming are treated synonymously with residing at a threshold. And it is 
in this space of the threshold where each of us is born as a unique beingand not just once as in our first birth, but where each of us is transformed again and again. The narrator pleads: 'Don't you see it [my existing] is like a child being born?' (p. 51). Becoming is a birth that is experienced in a field of sensibility through which one 'feels the tumult of newness' (p. 20). A newness that evokes fear and apprehension like a soon-to-be-born infant. She writes: 'But now I want plasma, I want to feed directly from the placenta. I'm a little frightened, still afraid to give myself over since the next instant is the unknown' (p. 3). In figuratively being born, we enter into the next instant again and again, living (but never reliving) the newness that is ours in each moment of the present. What is striking about Lispector's language is the mixture of the visceral concreteness of the body with the ephemeral, anticipatory state of the 'next instant'. This 'next instant' is always imminent and open to surprise ('Something is always about to happen' (p. 43)) and at the same time it is always predictable in its very unpredictability: 'And the only thing that awaits me is precisely the unexpected' (p. 44). Connecting the 'unexpected' here to birth stands somewhat in contrast to dominant preoccupations of western philosophy that instead identify death 'as the only thing that awaits us all'. In proposing natality as a model of unique becoming as opposed to mortality as our common final act, Lispector renders the nature of our existing as recurrent, and not something that takes its form against the background of a future finality. ${ }^{7}$

Like our first birth, our subsequent ones are not easy. Because they are accompanied by a deep uncertainty of the future, by the mystery of the 'next instant', living in the present can also be painful. The narrator expresses her quiet disappointment: 'Oh, living is so uncomfortable. Everything presses in: the body demands, the spirit never ceases, living is like being weary but being unable to sleep_living is upsetting' (p. 78). That is, to live in the present means that life becomes a 'delicately real' (p. 56) experience, where the veils through which we usually sense the world are cast off, even if only momentarily. The stories we use to plot the world and ourselves are the shifting sands upon which our uniqueness becomes precariously, if inevitably, attached but through which we cannot experience life fully.

Towards the end of the book, the narrator recounts a moment where this fullness of living appears. It is a moment of sensation of coming into being, a sensation of 'silence and light terror' (p. 71):

Because today, July 25, at five in the morning, I fell into a state of grace. It was a sudden sensation, but extremely soft. Luminosity smiled in the air: precisely that. It was the world sighing. I don't know how to explain it, in the same way that you don't know how to describe the dawn to a blind man. It's unsayable, what happened to me in a sense form ... (p. 71).

The aesthetic character of this state of grace, its 'sense form', remains unamenable to language. The narrator acknowledges that in its unsayability, the sensations remain just that, sensations, residing between 
spirit and body. It is as if they have an aura of untouchability and unapproachability hanging about them. She continues:

In that state, beyond the tranquil happiness that irradiates from people and things, there's a clarity that I call lightness only because in grace everything is so light. . . The body is transformed into a gift. And one feels it's a gift because one is experiencing, directly from the source, the suddenly unquestionable gift of miraculously and materially existing. ... . [Unlike the grace of the saints] it's simply the grace of a common person who suddenly transforms it into something real because it's common and human and recognizable. ... Discoveries, in this sense, are unsayable and uncommunicable. And unthinkable. That's why, when the state of grace came over me, I remained seated, quiet, silent. It's like an annunciation. Not preceded by angels, however. But it's as if the angel of life came to announce the world to me (pp. 72-73).

Lispector puts into relief the exquisiteness of living-an exquisiteness that is fleeting; for like all states no matter how graceful or magical, the moment of their appearance must pass. Coming into being is a one-off affair, flooded, however, with sensibility that can only be talked about as memory and reflection, and never to be relived at the same moment again. What is so striking about the passage here is the juxtaposition of Lispector's imagery of angels, miracles and gifts with the sheer banality of transformation: it can and does happen to anyone. Such moments of becoming, living, existing, are not just for sages, saints, or venerables. As the narrator claims, 'I wasn't meditating at all, there was no religiousness in me. I had just finished my coffee and I was simply living, sitting there with a cigarette burning down in the ashtray' (p. 73).

What Lispector's novel portrays is the ordinariness of the extraordinary event of becoming, and the extraordinary transformation that emerges amidst the ordinariness of our lives. She relays in poetic detail the time and space of transformation that takes hold of us again and again, redolent with anxieties and fears, as well as with the glory and sheer delight to be had in the moment. Although she writes of the instantaneousness of becoming, without plan or intentionality, hers is not the regular language of epiphany; in coupling it to birth it becomes an epiphany located in the small and subtle gestures of everyday life. Her work is a powerful, imaginative display of the liminal aspects of transformation. Educationally speaking, the metaphor of birth gives us an alternative imaginary of the kind of changes we seek to inspire in students, even if such changes are not within our control. That is, we 'conceive' educational demands for students' transformation and introduce students to new information and experiences; there is implicit in this that the student will in turn emerge as not someone merely different than before, but also renewed in her becoming. ${ }^{8}$ Pedagogically speaking, the aesthetic sensations that accompany this becoming signal the concrete, contextual nature of existing, for it is in our acute awareness of the instant, and the people and things that are part of this 
instant, through which a 'state of grace' is experienced. Thus, it is in relation to our material surroundings that we transcend the limits of ourselves. And this, I think, has something important to say to education, given the concrete realities of classroom life: the relationships to other bodies, other sensibilities, other ideas. What therefore remains to be explored more thoroughly here is precisely this relational, contextual aspect of becoming, and the ways in which metaphors of this liminal space of relationality might provide a more fulsome picture of the existential, transformative character of education.

\section{THE LIMINAL QUALITY OF RELATIONSHIPS}

Perhaps no other philosopher has devoted herself to mobilising metaphors of liminality more than Luce Irigaray. Her feminist project is one of transforming patriarchal symbolic practices through recourse to emphasising the relational, embodied qualities of human becoming which acts, she claims, to counterpose the primarily masculine imagery of depictions of ontology. As Caroline Wilson's paper in this issue outlines, such a project echoes what Luisa Muraro refers to as the maternal symbolic; it is a way of instituting new modes of relationality through the mobilisation of an alternative language. In line with this, Irigaray has focused on developing metaphors that speak to the time and space in between self and other, in between identity and difference. Hers is a philosophy of relationality through which she attempts to rethink human becoming as always already located in this experience of the threshold, and like both Lispector and Muraro, frequently writes of birth, newness and natality as well as integrating aspects of female corporeality into her language. In this sense, her work speaks directly to the pedagogical idea of transformation at the same time as it is firmly anchored in relationships.

One of Irigaray's most compelling metaphors is what she refers to as the 'placental economy', or placental exchange, which provides her with a way of drawing attention to the threshold where human existence itself is rooted in an encounter with the unknowable other. 'One of the distinctive features of the female body is its toleration of the other's growth within itself without incurring illness or death for either one of the living organisms' (1993b, p. 45). In a conversation with Hélène Rouch, an embryologist, Irigaray claims that this economy operates according to a different logic than that usually accorded it by patriarchal discourse. I quote from Rouch:

Firstly, I'll just remind us what the placenta is: it's a tissue, formed by the embryo, which, while being closely imbricated with the uterine mucosa remains separate from it. This has to be reiterated, because there's the commonly held view that the placenta is a mixed formation, half-maternal, half-fetal. However, although the placenta is a formation of the embryo, it behaves like an organ that is practically independent of it. It plays a mediating role on two levels. On the one hand, it's the mediating space between mother and fetus, which 
means that there's never a fusion of maternal and embryonic tissues. On the other hand, it constitutes a system regulating exchanges between the two organisms ... (1993b, pp. 38-39).

Women are not in an undifferentiated state with the child in utero. They are not one. Despite current popular discourse around motherhood which often positions women as being in a state of fusion with their foetuses, or regulates mothers' bodies under the assumption that everything they do has an immediate impact upon the unborn child, Rouch and Irigaray postulate a very different conception, highlighting the placenta's mediating role between self and other. This complex system of mediation is best captured again by Rouch:

The embryo is half-foreign to the maternal organism. Indeed, half of its antigens are paternal in origin. Because of this the mother should activate her defense mechanisms to reject this other to her self... [Yet] the placenta isn't some sort of automatic protection system. . . . On the contrary, there has to be a recognition of the other, of the non-self, by the mother, and therefore an initial reaction from her, in order for placental factors to be produced. The difference between the 'self' and other is, so to speak, continuously negotiated (1993b, pp. 40-41).

Here we see that the placenta is other to the mother, as is the foetus. In order for placental development to occur, this otherness that is the embryo must be 'recognised'. Life itself is dependent upon the recognition of an other. It is not dependent upon incorporating the other to make it one; rather, life is dependent upon a self-other relationship where each remains separate, yet interrelated (the placental exchange). The placenta is between mother and child, acting not as a barrier, but as a substance which mediates their exchange. It is not a 'border', but a membrane, a porous threshold which regulates mother-embryo interaction and yet keeps their otherness intact. As Rachel Jones (2011) writes, 'It thus allows differences to remain palpable between two beings who are nonetheless not straightforwardly separable' (p. 161).

Irigaray's next move is to see this 'economy' as a metaphor for reimagining existence as itself a relation to otherness. Thus, Irigaray moves from the raw materiality of the placenta as a biological substance, to its signification as a metaphor for the transcendent qualities of existencetranscendent in that human becoming is not simply about a biological interchange, but about an interaction with something other that exists beyond one's own corporeal limits. It approaches, for Irigaray, an ethical engagement with 'mystery', even if it is also incarnate. 'The placental economy is therefore an organized economy, one not in a state of fusion, which respects the one and the other. Unfortunately, our cultures... neglect or fail to recognize the almost ethical character of the fetal relation' (1993b, p. 41).

This ethical aspect of liminality is central to Irigaray's project, as it consists in respecting the otherness of the other. In order to highlight this 
relation, she elsewhere draws on the metaphors of touch and caress ${ }^{9}$ as another way of approaching what she refers to as the 'sensible transcendental' (1993a, p. 32): a sensible experience of the other which calls into being the 'unforeseeable nature of contact with otherness, beyond its own limits' (1993a, p. 211). That is, our becoming is in a sensible, material relation with an other which simultaneously enables us to exceed ourselves, to engage with the mystery of the unknowability of the other. Echoing the 'placental economy' here as one of exchange, the metaphors of touch and caress are mediating thresholds of becoming. I quote Irigaray at length:

No nourishment can compensate for the grace or work of touching. Touching makes it possible to wait, to gather strength, so that the other will return to caress and reshape, from within and from without, a flesh that is given back to itself in the gesture of love. The most subtly necessary guardian of my life is the other's flesh.... As he caresses me, he bids me neither to disappear nor to forget but rather to remember the place where, for me, the most intimate life is held in reserve. Searching for what has not yet come into being for himself, he invites me to become what I have not yet become. To realize a birth that is still in the future (1993a, p.187).

This birth that is 'not yet' is rooted here in the tactile, sensory dimensions of contact. Touch is a searching for what has not yet come into being at the same time as it 'invites' the other, through its grace, into this shared space for which there are no words, but only sensations. Such contact, consistent with Irigaray's emphasis on the sensible transcendental, opens up toward an unknowable future. The moment of contact - the instant as Lispector would say-is what enables each of us to exceed to ourselves and to become someone who has not yet been defined. Thus touch is not only about material limits, but always gestures to an opening of spirit through which a new birth is possible.

Irigaray's attempts to call into being the inbetweenness of relationality through metaphors such as the placenta and the caress, offer us two windows of insight into the qualities of relationships relevant for human becoming: 1) a respect for the otherness of the other; and 2) a respect for the other's becoming, that is, a respect for other's future-a becoming that is 'not yet'. In the first instance, in terms of education, respect for otherness forms the bedrock for bringing an ethical sensibility to our relationships. When read through the placental economy, the teacher-student relationship becomes one of mediation and exchange. Although each bears a different role, they nonetheless are linked through the porosity of the classroom and the practices they engage in within it (such as the texts they read, or the art they create, or the material spaces they inhabit). Such porosity is not about becoming fused or unified, but only works from a respect for the other's becoming. Resonating with Conroy's liminal education and teacher disposition here, the placental economy allows us to revision teacher-student relationships as having existential value for both parties, whereby each meet in an encounter that actually moves beyond the limits of their educa- 
tional roles. In the second instance, the respect for the other's future becoming would seem to be particularly suited to education, since futureoriented discourses constantly frame our reasons for teaching certain subject matter and for valuing certain kinds of academic performance over others. But the difference here is that it is only through the present moment that the future can have meaning. For example, in Irigaray's metaphor of touch, it is in one's contact with an other in the here and now through which the future opens up. This means that it should not be left solely to policy makers and curriculum developers to decide what kind of adults we want children to be in the future (or what kind of professionals we want adult students to become), but to find ways in our teaching to allow the future to be open-ended. This requires an engagement in the present moment-in all its subtlety - that resists its co-optation in an already defined future. Mobilising touch as a metaphor of pedagogical relationships means signalling that education is very much about the sensibilities incurred in the everyday contact teachers and students have with one another and how those sensibilities can then open up the question of becoming to a personal future that remains outside the dictates of politicians and other stakeholders in education-a becoming that is, as Irigaray says, 'not yet'. Thus what Irigaray's metaphors offer is a way of grounding the relational quality of transformation, making our interactions within educational settings bearers of ethical and ontological implications.

\section{LIMINAL PEDAGOGICAL RELATIONSHIPS AND EDUCATION}

If we shift from metaphors of growth or stages or outcomes, to ones involving the liminality of living, existing, and becoming-between body and spirit-then the teacher-student relationship correspondingly shifts. The specifically pedagogical, transformative relationship is therefore not about control or predicting the future, about learning a particular piece of subject matter, or about measuring outcomes, although these are all significant aspects of our educational work. It is, rather, about making room within educational discourses for the kind of existential, liminal aspects of the teacher-student relationship which already go on, even if we fail to name or address them. This does not mean that I think everything in education has to do with human becoming, or that we simply need to mobilise the term 'sensible transcendental' or 'placenta' or 'birth' and all will fall into proper focus. It is, rather, that in order to have some nuance in our educational practices, we need to begin to appreciate the subtle, unnameable dimensions of our life that do indeed have a profound impact on the kinds of teaching and learning that go on in our classrooms. This is why metaphor is so important, for the task is not to define, circumscribe, or predict these aspects of relationality, but to bring them into our sphere of attention so that they then can take their place within our conceptual work on education and our practical work with students. Acknowledging the inbetween spaces through which we become who we are in this moment, beyond the rigid intentionalities that often frame the work of teaching, 
opens up the possibility for approaching policy, assessment, and curriculum not only as guidelines, documents, or discourses, but fundamentally as practices that are always being played out materially, between bodies in the present, and unpredictably, against a future that is always unknown. So it is not that the future-oriented questions of what we teach and why we teach it are not central to the task of education; it is not that teachers (particularly in elementary and secondary education) can ignore the role they play in socialisation or that teachers can simply refuse to make academic judgements; it is that there is more than this to the work we do-if, that is, we believe that education indeed can have some transformative potential. It seems to me that if we are going to resist the increasingly market economy terms that are used to define our work, we need alternative vocabularies that can help us to manoeuvre around them better and to become more aware of the times that small moments of grace, those instants of living transformation, actually make a difference to who we as students and teachers become in the process.

This means using a language in our theorising and in our ways of reflecting upon practice that neither erases these relational dimensions, nor simply celebrates them, but that is mindful of how they offer texture and depth to our everyday engagement with curriculum, evaluation, and interpersonal encounters. This is not a conceptual language that attempts to capture fully the aesthetic dimensions of becoming, but a language that admits of its own limits in that it can never stand in for the experience itself. This is not to claim that experience is unmediated, but simply that it is its own 'thing' in the instant it happens, not given to replication or encapsulation. Thus, thinking about our encounters with students through metaphors of liminality gives us a way of approaching these encounters without entirely co-opting them under the hubris of understanding. As Wilson in this issue emphasises, language helps to name what has previously been left unnamed; at the same time, however, such naming does not suture over the experience of embodied existence. Touch, natality, newness and exchange are not definitions of what experience $i$, rather they offer us a method and approach for appreciating that these experiences shape profoundly the conditions of our educational settings. When we think of the common vulnerability teachers experience standing up in front of a class, the anxieties that grip students about to read aloud in front of their peers, the fear of failure, of which O'Donnell in this volume writes, that prevents students from speaking - all this cannot be 'converted' into language. Theorising and reflecting differently, through metaphor, through the liminal imagination, means approximating the aesthetic experience of existing and becoming, without assuming that our language can act as a substitute for the experience itself. At the beginning of this article, I wrote of the goosebumps on my skin and the teacher's breath on my cheek, and I 'name' an experience; but that experience still stands outside of understanding. What this article has had as its central focus is in fact how the limits of our understanding do not determine the limits of what happens to each of us in the moment of living, in the moment of becoming. Taking seriously the liminal experiences of our pedagogical relationships, with all 
their subtlety, ineffability and materiality, can help us reimagine the transformative potentialities of the educational landscape. In other words, not understanding our pedagogical experiences might just be the very life-affirming and risky stuff out of which education can be made. ${ }^{10}$

\section{Correspondence: Sharon Todd, Department of Education, Stockholm Uni-} versity, Frescativägen 54, Stockholm, SE 106 91, Sweden.

Email: sharon.todd@edu.su.se

\section{NOTES}

1. Castoriadis (1997) refers to pedagogy, stemming from the Greek paideia, as a process through which the newborn becomes a human being (pp. 129-130).

2. As will be seen in the discussion below, drawing on Lispector, spirit involves not only an intangibility, but a sense of being unbounded.

3. Deleuze rejects the idea of metaphor, claiming that it has been inherently tied to identity and analogy. Yet, his own use of rhizomes, lines of flight, and indeed the definition of the philosophical concept itself seems to intimate nonetheless a mode of thought that metaphor has often served to depict. I am using the term 'metaphor' instead of 'concept' in order to allude to the traces of literary (and indeed aesthetic) meaning that inhere in our philosophical renderings of educational practice.

4. See Masschelein's (2010) discussion of the importance the present and paying attention have in the context of an educational experiment.

5. Although not addressing directly the question of liminality, see also Maxine Greene's (1978, 2004) work on the relation between becoming and the arts.

6. The Portuguese title is Agua Viva, or literally, living water.

7. Natality, as it appears in Lispector's novel, is not the same as Hannah Arendt's (1959) reading of the term. The former is built on the experiential, corporeal aspects of becoming, while the latter is concerned with narrative and speech.

8. This metaphor of birth here functions differently than the Socratic mid-wife model of teaching, since for the latter, the idea is about 'delivering' from the m/other something that is already there, whereas for the former emphasis is not on the delivery as such, but on the moment of entering the world.

9. Her discussion of touch and the caress are part of an interpretative critique of Emmanuel Levinas's (1969) use of the terms in his Totality and Infinity.

10. I would like to acknowledge the feedback I received from the anonymous reviewers and from my fellow contributors to this volume.

\section{REFERENCES}

Arendt, H. (1959) The Human Condition (New York, Anchor Books).

Castoriadis, C. (1997) World in Fragments: Writings on Politics, Society, Psychoanalysis, and the Imagination, D. A. Curtis, trans. (Stanford, CA, Stanford University Press).

Conroy, J. C. (2004) Betwixt and Between: The Liminal Imagination, Education and Democracy (New York, Peter Lang).

Deleuze, G. and F. Guattari. (1994) What is Philosophy? G. Burchell and H. Tomlinson, trans. (London, Verso).

Dewey, J. (1969) [1938] Experience and Education (New York, Collier Books).

Greene, M. (1978) Landscapes of Learning (New York, Teachers College Press).

Greene, M. (2004) Releasing the Imagination: Essays on Education, the Arts, and Social Change (New York, National Association of Independent Schools). 
Irigaray, L. (1993a) An Ethics of Sexual Difference, C. Burke and G. C. Gill, trans. (Ithaca, NY, Cornell University Press).

Irigaray, L. (1993b) Je, Tu, Nous: Toward a Culture of Difference, A. Martin, trans. (New York, Routledge).

Jones, R. (2011) Irigaray: Toward a Sexuate Philosophy (London, Polity).

Levinas, E. (1969) Totality and Infinity: An Essay on Exteriority, A. Lingis, trans. (Pittsburgh, PA, Duquesne University Press).

Lispector, C. (1989) [1974] The Stream of Life, E. Lowe and E. Fitz, trans. (Minneapolis, MN, University of Minnesota Press).

Lusted, D. (1986) Why Pedagogy? Screen, 27.5, pp. 2-14.

Masschelein, J (2010) E-ducating the Gaze: The Idea of a Poor Pedagogy, Ethics and Education, 5.1, pp. 43-53.

Todd, S. (2003) Learning from the Other: Levinas, Psychoanalysis and Ethical Possibilities in Education (Albany, NY, State University of New York Press). 
Copyright of Journal of Philosophy of Education is the property of Wiley-Blackwell and its content may not be copied or emailed to multiple sites or posted to a listserv without the copyright holder's express written permission. However, users may print, download, or email articles for individual use. 